\title{
STUDY OF ANTIOXIDANT ACTIVITY OF FORMONONETIN BY IN VITRO METHOD
}

\author{
V. J. VISHNUVATHAN*, K. S. LAKSHMI, A. R. SRIVIDYA \\ SRM College of Pharmacy, Kattankulathur, Kancheepuram District, Tamilnadu India \\ Email: vishnuvj24@gmail.com
}

Received: 08 Jul 2016 Revised and Accepted: 29 Dec 2016

\begin{abstract}
Objective: Now the important field of research in phytomedicine is to search a new plant source as well as new phytoconstituents that have fewer side effects and low cost with the free radical scavenging activity.

Methods: Different in vitro models such as $\mathrm{DPPH}$, hydroxyl radical, hydrogen peroxide radical, nitric oxide radical and superoxide radical scavenging activity were performed using different concentrations of formononetin ranging from $0.1-50 \mu \mathrm{g} / \mathrm{ml}$.

Results: Formononetin showed only $84.39 \%$ inhibitory activity against DPPH radical and it was found to be $16 \%$ less than the butylated hydroxytoluene with the IC 50 value of $4.65 \mu \mathrm{g} / \mathrm{ml}$ concentration. In scavenging hydroxyl radicals, formononetin inhibited only $67.63 \%$ with the IC 50 value of $9.48 \mu \mathrm{g} / \mathrm{ml}$ concentration and it showed $12 \%$ lesser inhibitory activity than standard alpha-tocopherol. Formononetin could able to scavenge maximum $73.53 \%$ of hydrogen peroxide radicals with the $\mathrm{IC}_{50}$ value of $4.75 \mu \mathrm{g} / \mathrm{ml}$ and its activity of scavenging hydrogen peroxide were found to be $10 \%$ less than the standard ascorbic acid. Formononetin showed $94.33 \%$ nitric oxide radical inhibitory activity with the IC 50 value of $5.0 \mu \mathrm{g} / \mathrm{ml}$ and it showed $6 \%$ lesser activity when compared to standard quercetin. Formononetin showed $94.79 \%$ activity against the scavenging of superoxide radical with the $\mathrm{IC}_{50}$ value of $4.27 \mu \mathrm{g} / \mathrm{ml}$. Superoxide inhibitory activity of formononetin was $5.3 \%$ less than the standard quercetin.
\end{abstract}

Conclusion: All these results suggested that, formononetin is a good natural antioxidant which is capable of scavenging almost all types of free radicals. So this could be used to treat various diseases like diabetes, atherosclerosis, cancers, the aging and cardiovascular disease which is being caused by free radicals.

Keywords: Formononetin, Antioxidant activity, DPPH, Hydrogen peroxide radical scavenging activity, Hydroxyl radical scavenging activity, Nitric oxide radical scavenging activity, Superoxide radical scavenging activity

(C) 2016 The Authors. Published by Innovare Academic Sciences Pvt Ltd. This is an open access article under the CC BY license (http://creativecommons.org/licenses/by/4. 0/] DOI: http://dx.doi.org/10.22159/ijpps.2017v9i2.13964

\section{INTRODUCTION}

Less than 50 y ago, the presence of free radicals in biological materials was discovered. Denham Harman stated that, the in vivo oxygen radicals might be formed as a byproduct of enzymatic reactions. Pandora's Box in 1956 described that free radicals are responsible for cellular damage, mutagenesis, cancer and the degenerative process of biological aging. After the discovery of the enzyme superoxide dismutase (SOD) by McCord and Fridovich, the science of free radical entered into a second era. Being an important component in the biological system many researchers started to perform investigations about the oxidative damage to DNA, Protein, lipids as well as other components of the cell. After knowing the advantageous biological effects of free radicals, a third era began. Clinicians started to show much attention to the field of redox regulations because oxidative stress found to play an important role in many disease conditions. The important aspect of life is to maintain a balance between advantageous and detrimental effects of free radicals.

By the univalent reductions of triplet state, molecular oxygen ${ }^{3} \mathrm{O}_{2}$ superoxide anion is formed via enzymes like NAD (P) $\mathrm{H}$ oxidases and xanthine oxidases. It is also produced non-enzymatically by the compounds of the mitochondrial electron transport chain. Superoxide gets converted into hydrogen peroxide by SOD. In the absence of enzyme, superoxide gets converted into hydrogen peroxide and singlet oxygen in the biological tissues. Hydrogen peroxide gets converted into highly reactive hydroxyl radicals in the presence of reduced transition metals like ferrous and cuprous ions. Catalase and glutathione peroxidase enzymes convert hydrogen peroxide into water.

By the oxidation of one of the terminal guanidino nitrogen atoms of L-arginine, nitrogen free radicals are produced in a higher organism which is catalyzed by NOS enzymes. NO gets converted into various reactive nitrogen species such as nitronium cation (NO+) nitroxyl anion, peroxynitrite (ONOO-) depending upon the microenvironment [1]. In the broad sense, free radicals include related reactive species such as excited states that lead to the formation of free radicals, which has a very short life with half life in a millemicro-nanoseconds.

The substances that neutralize the free radicals are called antioxidants. Every cell has an adequate protective mechanism such as superoxide dismutase (SOD), glutathione peroxidase, glutathione reductase, thioredoxin, thiols and disulfide bonding against any harmful effects of free radicals. At different stages such as prevention, interception, and repair, antioxidants neutralize free radicals. The generations of pro-oxidant in the form of ROS and RNS are effectively kept in check by an antioxidant defense mechanism in the normal healthy human body [2].

Free radicals are the natural by-products of our own metabolism, which are electrically charged. Molecules that attack our cells, tearing through the cellular membrane to react and create havoc with the nucleic acid, proteins and enzymes present in the body. Free radicals are capable of causing the cells to lose their structure, functions and can eventually destroy; such conditions in the cells are referred as oxidative stress. Free radicals are continuously produced by our body's use of oxygen through respiration; some cell-mediated immune functions, environmental pollutants, cigarette smoke, automobile exhaust, radiations and the pesticide could trigger the formation of free radicals to a major extent.

Normally our body has the capacity to balance the amount of free radical generation as well as a defense mechanism to protect the cells from the damage that are caused by free radicals. Antioxidant defense mechanism present in the cell protects the body when the amount of free radical formation is within the normal physiological level. Individuals balance capacity between free radical and cell defense mechanism plays an important role in disease scenario. Thorough understanding of various physiologically significant free 
radicals is paramount importance before the search of free radical scavengers or the antioxidant principles to treat various physiological disorders caused by free radicals [3].

Damage to the vital cellular molecules, including DNA, proteins, and lipids occurs, due to the damage of the cellular antioxidant defense mechanism by ionizing radiations. Among the cellular components, genomic DNA is the most important target in the cells, which gets damaged by the ionizing radiations. Strand break and cross-link of intra and interstrand type occur in DNA due to ionizing radiations. Due to the reactions of hydroxyl radicals generated by ionizing radiations with polyunsaturated fatty acid leads to the formation of malondialdehyde which is the byproduct of lipid peroxidation forms adduct with cellular DNA. With enzymatic and non-enzymatic reactions, antioxidant defense system present in the cells controls the deleterious effect of ROS and detoxifies the same [4].

During the aging process as well as in various disease progression, free radicals are believed to play a central role in causing the damage to the cells. In the past few decades, the medicinal value of plants has assumed to an important dimension due to the discovery of various antioxidants that compact oxidative stress through their redox active secondary metabolite as well as their lesser side effects, when compared to synthetic drugs. Plants are considered to be invaluable sources of new drugs and plant-based antioxidants are preferred now a day due to their safety. For the drug development, plant-derived bioactive components are considered to be an important candidate [5] In this paper, we have selected formononetin, a phytoconstituents that are present in small quantity in the majority of the plant and its antioxidant activity has been carried by different methods in vitro.

\section{MATERIALS AND METHODS}

\section{Materials}

Formononetin (TCI chemicals, India), DPPH (2,2-diphenyl-1picrylhydrazyl) (Sigma-aldrich, India), butylated hydroxyl toluene (LOBA, India), deoxyribose (MERCK India), alpha-tocopherol (TCI chemicals, India), quercetin (TCI chemicals, India), hydrogen peroxide (SD fine chemicals, India), Nitro blue tetrazolium (Sigmaaldrich, India), dimethyl sulphoxide (DMSO) (SD fine chemicals, India), riboflavin (Sigma-aldrich, India).

\section{Methods}

Assessment of In vitro antioxidant activity of formononetin.

\section{DPPH radical scavenging activity}

To $1 \mathrm{ml}$ of $0.1 \mathrm{mmol}$ of DPPH radical solution (prepared in methanol), $3 \mathrm{ml}$ of various concentrations such as $0.1,0.25,0.5,1.0$, 2.5, 5.0, 10.025 , and $50 \mu \mathrm{g} / \mathrm{ml}$ was added. The absorbance was measured at $517 \mathrm{~nm}$. Butylated hydroxytoluene (BHT) was used as positive control. This activity has been expressed as \% inhibition DPPH radical scavenging. The test was carried out in triplicate and the results are averaged [6]. The percentage inhibitory activity of DPPH radical was calculated by using the following formula

$$
\text { Percentage of Inhibition }=\frac{(\mathrm{A} 0-\mathrm{A} 1)}{\mathrm{A} 0} \times 100
$$

Where $A_{0}$ is absorbance of control and $A_{1}$ is absorbance of the test sample

\section{Hydroxyl radical inhibitory activity}

The reaction mixture was prepared by adding deoxyribose $(3 \mathrm{mmol}$, $0.2 \mathrm{ml})$, ferric chloride $(0.1 \mathrm{mmol}, 0.2 \mathrm{ml})$ and hydrogen peroxide $(2$ mmol, $0.2 \mathrm{ml}$ ) in phosphate buffer saline (PBS; pH 7.4, $20 \mathrm{mmol}$ ). Various concentrations of the formononetin such as $0.1,0.25,0.5$, $1.0,2.5 .5 .0,10.0,25.0$, and $50 \mu \mathrm{g}$ at a volume of $0.2 \mathrm{ml}$ in DMSO was added to the reaction mixture to make the total volume of $1.1 \mathrm{ml}$ reaction mixture. For the period of $30 \mathrm{~min}$, the reaction mixture was kept in boiling water bath, then its absorbance was measured at 532 $\mathrm{nm}$. By using the following formula the percentage inhibition of hydroxyl radical ion by formononetin was measured. Alphatocopherol was used as a positive control [7]. The test was performed in a triplicate manner and the results are averaged.

$$
\text { Percentage of inhibition }=\frac{(\mathrm{A} 0-\mathrm{A} 1)}{\mathrm{A} 0} \times 100
$$

Where $A_{0}$ is absorbance of control and $A_{1}$ is absorbance of the test sample

\section{Nitric oxide inhibitory activity}

$0.5 \mathrm{ml}$ of $0.1 \mathrm{M}$ PBS (pH 7.4) was added to $2 \mathrm{ml}$ of $10 \mathrm{mmol}$ sodium nitroprusside and mixed well. To this mixture, various concentrations such as $0.1,0.25,0.5,1.0,2.5 .5 .0,10.0,25.0$, and 50 $\mu \mathrm{g}$ of $0.5 \mathrm{ml}$ of formononetin was added and incubated for $150 \mathrm{~min}$ at $25^{\circ} \mathrm{C}$. After the incubation period, its absorbance was measured at $546 \mathrm{~nm}$. In this test, quercetin was used as positive control. The percentage inhibition of nitric oxide radical by formononetin was calculated by using the following formula [8]. The test was repeated in a triplicate manner and results are averaged.

$$
\text { Percentage of inhibition }=\frac{(\mathrm{A} 0-\mathrm{A} 1)}{\mathrm{A} 0} \times 100
$$

Where $A_{0}$ is absorbance of control and $A_{1}$ is absorbance of the test sample

\section{Hydrogen peroxide inhibitory activity}

To $2 \mathrm{ml}$ of $30 \mathrm{mmol}$ hydrogen peroxide, $1 \mathrm{ml}$ of various concentrations of formononetin such as $0.1,0.25,0.5,1.0,2.5$. 5.0, $10.0,25.0$, and $50 \mu \mathrm{g}$ dissolved in PBS ( $\mathrm{pH} 7.4$ ) was added and its absorbance was measured at $230 \mathrm{~nm}$. The hydrogen peroxide inhibitory activity was calculated by using the following formula. Ascorbic acid was used as a reference compound [9]. The activity was subject to triplicate and the results are averaged.

$$
\text { Percentage of inhibition }=\frac{(\mathrm{A} 0-\mathrm{A} 1)}{\mathrm{A} 0} \times 100
$$

Where $A_{0}$ is absorbance of control and $A_{1}$ is absorbance of the test sample

\section{Superoxide anion radical scavenging activity}

The assay mixture was prepared by mixing $0.5 \mathrm{ml}$ of different concentrations of formononetin solution such as $0.1,0.25,0.5,1.0$, 2.5. 5.0, 10.0, 25.0,and $50 \mu \mathrm{g} / \mathrm{ml}$ with $0.1 \mathrm{ml}(1.5 \mathrm{mmol} \mathrm{NBT})$ of nitro blue tetrazolium dye (NBT), $0.2 \mathrm{ml}(0.1 \mathrm{M})$ of EDTA, $0.05 \mathrm{ml}(0.12$ mmol) of riboflavin and $2.55 \mathrm{ml}(0.677 \mathrm{M})$ of Phosphate buffer. The Control was set up with DMSO instead of a sample. The reaction mixture was illuminated for $30 \mathrm{~min}$ and then the absorbance was measured at $560 \mathrm{~nm}$. Quercetin was used as a reference standard[10]. All the test was performed triplicate and the results averaged.

$$
\text { Percentage of inhibition }=\frac{(\mathrm{A} 0-\mathrm{A} 1)}{\mathrm{A} 0} \times 100
$$

Where $A_{0}$ is absorbance of control and $A_{1}$ is absorbance of the test sample

\section{Statistical analysis}

The test was carried out in triplicate and the results were analyzed by using two-way ANOVA followed by a bonferroni post comparison test. All the values were expressed as mean \pm SEM where $n=3$.

\section{RESULTS AND DISCUSSION}

In DPPH radical scavenging method, formononetin showed the maximum inhibitory activity at the concentration of $50 \mu \mathrm{g} / \mathrm{ml}$. The percentage of inhibition of DPPH radical by the formononetin and butylated hydroxytoluene (BHT) was found to be $78.81 \pm 1.57$ and $93.38 \pm 1.839$ respectively. When compared to the standard butylated hydroxy toluene (BHT) formononetin showed only $84.39 \%$ inhibitory activity only. Formononetin inhibitory activity of DPPH radical was found to be $16 \%$ less than the standard. The percentage of inhibition of DPPH radical found to increase with the concentration of formononetin. The values for percentage inhibition of DPPH radicals at concentrations of $0.1 \mu \mathrm{g} / \mathrm{ml}, 0.25 \mu \mathrm{g} / \mathrm{ml}, 0.5$ $\mu \mathrm{g} / \mathrm{ml}, 1.0 \mu \mathrm{g} / \mathrm{ml}, 2.5 \mu \mathrm{g} / \mathrm{ml}, 5.0 \mu \mathrm{g} / \mathrm{ml}, 10 \mu \mathrm{g} / \mathrm{ml}, 25 \mu \mathrm{g} / \mathrm{ml}$, and 50 $\mu \mathrm{g} / \mathrm{ml}$ of formononetin was found to be $12.20 \pm 1.34,19.26 \pm$ 
$1.04 .29 .13 \pm 1.25,35.36 \pm 1.06, \quad 47.50 \pm 1.63, \quad 53.75 \pm 1.24, \quad 65.48 \pm 0.90$ $72.08 \pm 1.55$ and $78.81 \pm 1.57$ respectively; corresponding values for the butylated hydroxytoluene (at the same concentrations) were $18.56 \pm 1.180,26.08 \pm 1.062,35.81 \pm 1.013,47.60 \pm 1.649,61.03 \pm 1.334$,
$74.34 \pm 1.170, \quad 82.36 \pm 1.685, \quad 88.20 \pm 1.484$ and $93.38 \pm 1.839$ respectively. IC 50 value of formononetin and butylated hydroxytoluene was found to be 4.65 and $1.1 \mu \mathrm{g} / \mathrm{ml}$ respectively. The results are shown in table and fig. 1.

Table 1: Percentage inhibition of DPPH radical by formononetin at different concentrations was carried out and compared with the same concentration of butylated hydroxyl toluence. i.e. standard. The Results represent the means \pm SEM (standard error of mean) from at least three separate experiments

\begin{tabular}{llllllllll}
\hline Compound & \multicolumn{2}{l}{ Concentrations $(\boldsymbol{\mu g} / \mathbf{m l})$} & & & & & \\
\cline { 2 - 9 } & $\mathbf{5 0}$ & $\mathbf{2 5}$ & $\mathbf{1 0}$ & $\mathbf{5}$ & $\mathbf{2 . 5}$ & $\mathbf{1}$ & $\mathbf{0 . 5}$ & $\mathbf{0 . 2 5}$ & $\mathbf{0 . 1}$ \\
\hline Formononetin & $78.81 \pm 1$. & $72.08 \pm 1$ & $65.48 \pm 0.9$ & $53.75 \pm 1.2$ & $47.50 \pm 1.6$ & $35.36 \pm 1.0$ & $29.13 \pm 1.2$ & $19.26 \pm 1.0$ & $12.20 \pm$ \\
& $57^{* * *}$ & $.55^{* * *}$ & $0^{* * *}$ & $4^{* * *}$ & $3^{* * *}$ & $6^{* * *}$ & $5^{*}$ & $4^{*}$ & $1.34^{*}$ \\
Butylated & $93.38 \pm 1$. & $88.20 \pm 1$ & $82.36 \pm 1.6$ & $74.34 \pm 1.1$ & $61.03 \pm 1.3$ & $47.60 \pm 1.6$ & $35.81 \pm 1.0$ & $26.08 \pm 1.0$ & $18.56 \pm$ \\
Hydroxy & 839 & .484 & 85 & 70 & 34 & 49 & 13 & 62 & 1.180 \\
Toluene (BHT) & & & & & & & & 1.1 \\
\hline
\end{tabular}

\section{DPPH Scavening Activity}

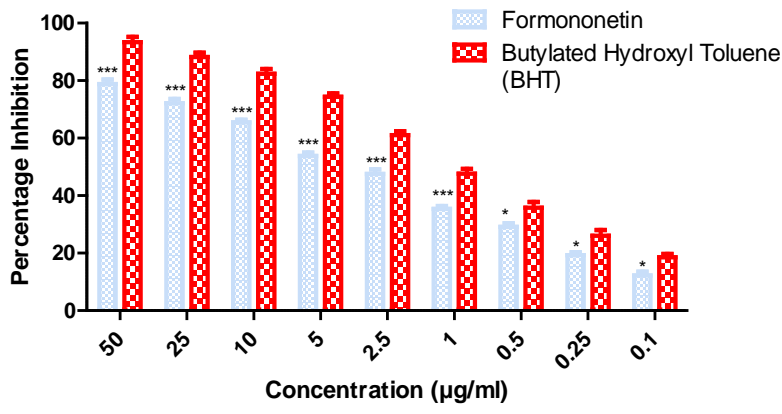

Fig. 1: DPPH radical scavenging activity of formononetin was calculated and compared with butylated hydroxl toluence i.e. standard. The activity increased in time and concentration dependent manner. The results represent the means \pm SEM (standard error of mean) from at least three separate experiments
In hydroxyl radical scavenging activity, formononetin showed the maximum inhibitory activity at the concentration of $50 \mu \mathrm{g} / \mathrm{ml}$. Formononetin can able to inhibit only $67.63 \%$ of hydroxyl radical and standard alpha-tocopherol could able to inhibit $76.00 \%$. When compared to the standard alpha-tocopherol, formononetin inhibitory activity was found to be $88.98 \%$ and it has $12 \%$ lesser inhibitory activity of hydroxyl radical than the standard. The inhibitory activity of hydroxyl radical was found to increase with the increase in the concentration. The values for percentage inhibition of hydroxyl radicals at concentrations of $0.1 \mu \mathrm{g} / \mathrm{ml}, 0.25 \mu \mathrm{g} / \mathrm{ml}, 0.5$ $\mu \mathrm{g} / \mathrm{ml}, 1.0 \mu \mathrm{g} / \mathrm{ml}, 2.5 \mu \mathrm{g} / \mathrm{ml}, 5.0 \mu \mathrm{g} / \mathrm{ml}, 10 \mu \mathrm{g} / \mathrm{ml}, 25 \mu \mathrm{g} / \mathrm{ml}$, and 50 $\mu \mathrm{g} / \mathrm{ml}$ of formononetin was found to $4.62 \pm 0.54,9.25 \pm 0.68$, $13.44 \pm 1.36, \quad 21.05 \pm 1.37, \quad 30.95 \pm 1.82, \quad 45.31 \pm 2.08, \quad 52.70 \pm 1.92$, $60.29 \pm 1.56$ and $67.63 \pm 0.95$ respectively. The corresponding values for the alpha-tocopherol (at the same concentrations) were $11.24 \pm 0.650,17.54 \pm 1.175,26.41 \pm 1.500,35.43 \pm 0.991,47.39 \pm 1.374$, $51.26 \pm 0.678, \quad 59.82 \pm 0.840, \quad 70.76 \pm 1.319$ and $\quad 76.00 \pm 0.770$ respectively. $\mathrm{IC}_{50}$ values of formononetin and alpha-tocopherol was found to be 9.48 and $4.87 \mu \mathrm{g} / \mathrm{ml}$ respectively. The results are shown in the table and fig. 2.

Table 2: Percentage inhibition of hydroxyl radical by formononetin at different concentrations was carried out and compared with the same concentration of alpha-tocopherol. i.e. standard. The results represent the means \pm SEM (standard error of mean) from at least three separate experiments

\begin{tabular}{|c|c|c|c|c|c|c|c|c|c|c|}
\hline \multirow[t]{2}{*}{ Compound } & \multicolumn{9}{|c|}{ Concentrations $(\mu \mathrm{g} / \mathrm{ml})$} & \multirow{2}{*}{$\begin{array}{l}\mathrm{IC}_{50} \text { in } \\
\mu \mathrm{g} / \mathrm{ml}\end{array}$} \\
\hline & 50 & 25 & 10 & 5 & 2.5 & 1 & 0.5 & 0.25 & 0.1 & \\
\hline Formonone & $67.63 \pm 0.9$ & $60.29 \pm 1.5$ & $52.70 \pm 1.9$ & $45.31 \pm 2.0$ & $30.95 \pm 1.8$ & $21.05 \pm 1.3$ & $13.44 \pm 1.3$ & $9.25 \pm 0.6$ & $4.62 \pm 0$ & \\
\hline $\operatorname{tin}$ & $5^{* * *}$ & $6^{* * *}$ & $2^{* *}$ & $8^{*}$ & $2^{* * *}$ & $7^{* * *}$ & $6^{* * *}$ & $8^{* * *}$ & $54^{* *}$ & 9.48 \\
\hline Alpha- & $76.00 \pm 0.7$ & $70.76 \pm 1.3$ & $59.82 \pm 0.8$ & $51.26 \pm 0.6$ & $47.39 \pm 1.3$ & $35.43 \pm 0.9$ & $26.41 \pm 1.5$ & $17.54 \pm 1$ & $11.24 \pm 0$ & \\
\hline Tocopherol & 70 & 19 & 40 & 78 & 74 & 91 & 00 & 175 & .650 & 4.87 \\
\hline
\end{tabular}

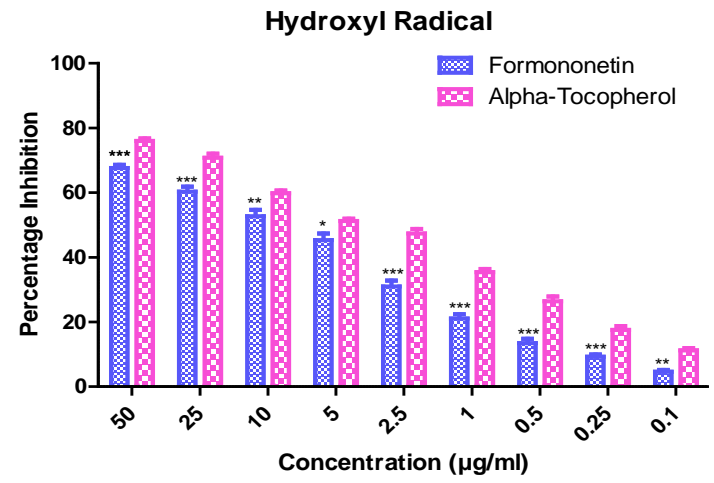

Fig. 2: Hydroxyl radical scavenging activity of formononetin was calculated and compared with alpha-tocopherol i.e. standard. The activity increased in time and concentration dependent manner. The results represent the means \pm SEM (standard error of mean) from at least three separate experiments
Formononetin could able to scavenge maximum $73.53 \%$ of hydrogen peroxide radicals whereas standard ascorbic acid could able to inhibit $83.85 \%$ at the concentration of $50 \mu \mathrm{g} / \mathrm{ml}$. When compared to the standard formononetin has $90.07 \%$ inhibitory activity and its activity of scavenging hydrogen peroxide was found to be $10 \%$ less than the standard ascorbic acid.

Percentage of inhibition of hydrogen peroxide radical by formononetin and ascorbic acid found to increase with the concentration. The values for percentage inhibition of hydrogen peroxide radicals at concentrations of $0.1 \mu \mathrm{g} / \mathrm{ml}, 0.25 \mu \mathrm{g} / \mathrm{ml}, 0.5 \mu \mathrm{g} / \mathrm{ml}, 1.0 \mu \mathrm{g} / \mathrm{ml}, 2.5 \mu \mathrm{g} / \mathrm{ml}$, $5.0 \mu \mathrm{g} / \mathrm{ml}, 10 \mu \mathrm{g} / \mathrm{ml}, 25 \mu \mathrm{g} / \mathrm{ml}$, and $50 \mu \mathrm{g} / \mathrm{ml}$ of formononetin was found to $10.20 \pm 0.68,17.68 \pm 2.37,25.82 \pm 1.22,34.40 \pm 2.13,46.25 \pm 1.02$, $52.58 \pm 1.47,59.67 \pm 1.34,66.46 \pm 1.52$ and $73.53 \pm 1.33$ respectively. The corresponding values for the ascorbic acid (at the same concentrations) were $17.03 \pm 1.329, \quad 25.68 \pm 1.253, \quad 35.84 \pm 1.613, \quad 48.72 \pm 1.342$, $53.81 \pm 1.482,59.84 \pm 1.554,66.39 \pm 0.995,74.01 \pm 1.684$, and $83.85 \pm 1.529$ respectively. $\mathrm{IC}_{50}$ value of formononetin and ascorbic acid was found to be 4.75 and $2.32 \mu \mathrm{g} / \mathrm{ml}$ respectively. The results are shown in table and fig. 3. 
Table 3: Percentage inhibition of hydrogen peroxide radical by formononetin at different concentrations was carried out and compared with the same concentration of ascorbic acid. i.e. Standard. The results represent the means \pm SEM (standard error of mean) from at least three separate experiments

\begin{tabular}{|c|c|c|c|c|c|c|c|c|c|c|}
\hline \multirow[t]{2}{*}{ Compound } & \multicolumn{9}{|c|}{ Concentrations $(\mu \mathrm{g} / \mathrm{ml})$} & \multirow{2}{*}{$\begin{array}{l}\mathrm{IC}_{50} \text { in } \\
\mu \mathrm{g} / \mathrm{ml}\end{array}$} \\
\hline & 50 & 25 & 10 & 5 & 2.5 & 1 & 0.5 & 0.25 & 0.1 & \\
\hline Formonone & $73.53 \pm 1.3$ & $66.46 \pm 1.5$ & $59.67 \pm 1.3$ & $52.58 \pm 1.4$ & $46.25 \pm 1.0$ & $34.40 \pm 2.1$ & $25.82 \pm 1.2$ & $17.68 \pm 2.3$ & $10.20 \pm 0$ & \\
\hline $\operatorname{tin}$ & $3^{* * *}$ & $2^{* *}$ & $4^{*}$ & $7^{*}$ & $2^{* *}$ & $3^{* * *}$ & $2^{* * *}$ & $7^{* *}$ & $.68^{*}$ & 4.75 \\
\hline Ascorbic & $83.85 \pm 1.5$ & $74.01 \pm 1.6$ & $66.39 \pm 0.9$ & $59.84 \pm 1.5$ & $53.81 \pm 1.4$ & $48.72 \pm 1.3$ & $35.84 \pm 1.6$ & $25.68 \pm 1.2$ & $17.03 \pm 1$ & \\
\hline acid & 29 & 84 & 95 & 54 & 82 & 42 & 13 & 53 & .329 & 2.32 \\
\hline
\end{tabular}

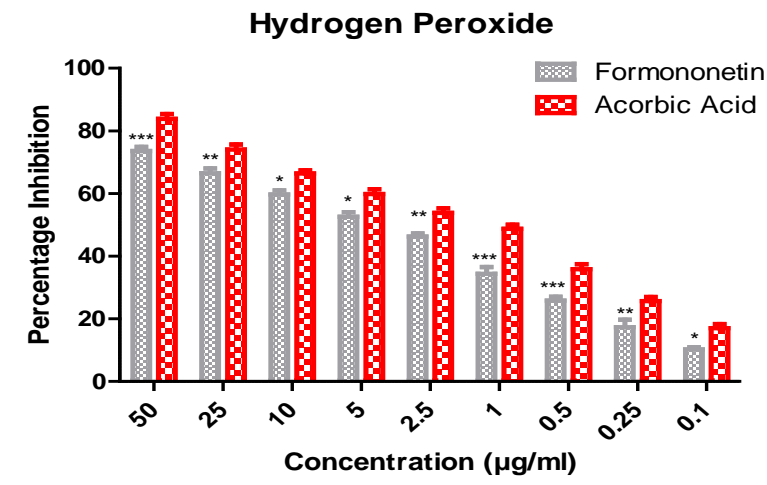

Fig. 3: Hydrogen peroxide radical scavenging activity of formononetin was calculated and compared with ascorbic acid i.e. standard. The activity increased in time and concentration dependent manner. The results represent the means \pm SEM (standard error of mean) from at least three separate experiments
In the scavenging of nitric oxide radical's formononetin showed $71.15 \%$ inhibition and standard quercetin showed $75.42 \%$ at 50 $\mu \mathrm{g} / \mathrm{ml}$ concentration. The percentage of inhibition by both formononetin and standard quercetin found to increase with their concentration. In our study formononetin showed $94.33 \%$ nitric oxide radical inhibitory activity and it has $6 \%$ lesser activity when compared to standard quercetin.

The values for percentage inhibition of nitric oxide radicals at concentrations of $0.1 \mu \mathrm{g} / \mathrm{ml}, 0.25 \mu \mathrm{g} / \mathrm{ml}, 0.5 \mu \mathrm{g} / \mathrm{ml}, 1.0 \mu \mathrm{g} / \mathrm{ml}, 2.5$ $\mu \mathrm{g} / \mathrm{ml}, \quad 5.0 \mu \mathrm{g} / \mathrm{ml}, \quad 10 \mu \mathrm{g} / \mathrm{ml}, 25 \mu \mathrm{g} / \mathrm{ml}$, and $50 \mu \mathrm{g} / \mathrm{ml}$ of formononetin was found to $14.42 \pm 0.60,22.79 \pm 0.62,27.89 \pm 0.89$ $33.91 \pm 0.96,44.03 \pm 1.09,50.78 \pm 0.71,55.17 \pm 1.19,63.80 \pm 0.70$ and $71.15 \pm 1.10$ respectively. The corresponding values for the quercetin (at the same concentrations) were 18.53 \pm 0.857 , $26.91 \pm 0.382, \quad 31.53 \pm 0.817, \quad 37.60 \pm 1.094, \quad 48.28 \pm 0.6801$, $54.99 \pm 0.136, \quad 59.35 \pm 0.562, \quad 67.90 \pm 0.180$ and $75.42 \pm 1.209$ respectively. IC 50 value of formononetin and quercetin was found to be 5.0 and $2.6 \mu \mathrm{g} / \mathrm{ml}$ concentrations respectively. The results are shown in table and fig. 4 .

Table 4: Percentage inhibition of nitric oxide radical by formononetin at different concentrations was carried out and compared with the same concentration of quercetin. i.e. Standard. The results represent the means \pm SEM (standard error of mean) from at least three separate experiments

\begin{tabular}{|c|c|c|c|c|c|c|c|c|c|c|}
\hline \multirow[t]{2}{*}{ Compound } & \multicolumn{9}{|c|}{ Concentrations $(\mu \mathrm{g} / \mathrm{ml})$} & \multirow{2}{*}{$\begin{array}{l}\mathrm{IC}_{50} \text { in } \\
\mu \mathrm{g} / \mathrm{ml}\end{array}$} \\
\hline & 50 & 25 & 10 & 5 & 2.5 & 1 & 0.5 & 0.25 & 0.1 & \\
\hline \multirow{4}{*}{$\begin{array}{l}\text { Formonone } \\
\text { tin } \\
\text { Quercetin }\end{array}$} & $71.15 \pm 1.1$ & $63.80 \pm 0.7$ & $55.17 \pm 1.1$ & $50.78 \pm 0.7$ & $44.03 \pm 1.09$ & $33.91 \pm 0.9$ & $27.89 \pm 0.8$ & $22.79 \pm 0.6$ & $14.42 \pm 0$ & \multirow{3}{*}{5.0} \\
\hline & $0^{* *}$ & $0^{*}$ & $9^{* *}$ & $1^{* *}$ & $* *$ & $6^{*}$ & $9^{*}$ & $2^{*}$ & $.60^{*}$ & \\
\hline & $75.42 \pm 1.2$ & $67.90 \pm 0.1$ & $59.35 \pm 0.5$ & $54.99 \pm 0.1$ & $48.28 \pm 0.68$ & $37.60 \pm 1.0$ & $31.53 \pm 0.8$ & $26.91 \pm 0.3$ & $18.53 \pm 0$ & \\
\hline & 09 & 80 & 62 & 36 & 01 & 94 & 17 & 82 & .857 & 2.6 \\
\hline
\end{tabular}

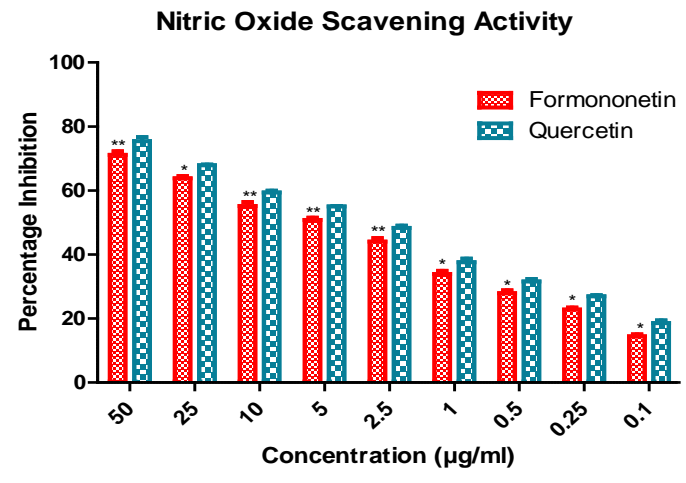

Fig. 4: Nitric oxide scavenging activity of formononetin was calculated and compared with qercertin i.e. standard. The activity increased in time and concentration dependent manner. The results represent the means \pm SEM (standard error of mean) from at least three separate experiments
In superoxide scavenging activity, formononetin showed $74.07 \%$ inhibition and standard quercetin showed $79.09 \%$ inhibition at the concentration of $50 \mu \mathrm{g} / \mathrm{ml}$. Formononetin showed $94.79 \%$ activity against the scavenging of superoxide radical. Formononetin super oxide inhibitory activity was $5.3 \%$ less than the standard quercetin.

The values for percentage inhibition of superoxide radicals at concentrations of $0.1 \mu \mathrm{g} / \mathrm{ml}, 0.25 \mu \mathrm{g} / \mathrm{ml}, 0.5 \mu \mathrm{g} / \mathrm{ml}, 1.0 \mu \mathrm{g} / \mathrm{ml}$, $2.5 \mu \mathrm{g} / \mathrm{ml}, 5.0 \mu \mathrm{g} / \mathrm{ml}, 10 \mu \mathrm{g} / \mathrm{ml}, 25 \mu \mathrm{g} / \mathrm{ml}$, and $50 \mu \mathrm{g} / \mathrm{ml}$ of formononetin was found to $12.05 \pm 0.47,20.16 \pm 0.83,29.31 \pm 1.48^{*}$ $37.46 \pm 0.65,45.69 \pm 1.01,57.09 \pm 1.07,64.68 \pm 1.04,69.72 \pm 0.94$ and $74.97 \pm 0.97$ respectively.

The corresponding values for the quercetin (at the same concentrations) were 16.19 $\pm 0.325,24.47 \pm 0.594,33.61 \pm 0.981$, $41.33 \pm 0.479, \quad 49.45 \pm 0.406, \quad 61.83 \pm 0.487, \quad 69.68 \pm 1.125$ $74.40 \pm 1.153$ and $79.09 \pm 0.807$ respectively. IC 50 value of formononetin and quercetin was found to be 4.27 and $2.6 \mu \mathrm{g} / \mathrm{ml}$ respectively. The results are shown in table and fig. 5. 
Table 5: Percentage inhibition of super oxide radical by formononetin at different concentrations was carried out and compared with the same concentration of quercetin. i.e. Standard. The results represent the means \pm SEM (standard error of mean) from at least three separate experiments

\begin{tabular}{|c|c|c|c|c|c|c|c|c|c|c|}
\hline \multirow[t]{2}{*}{ Compound } & \multicolumn{9}{|c|}{ Concentrations $(\mu \mathrm{g} / \mathrm{ml})$} & \multirow{2}{*}{$\begin{array}{l}I_{50} \text { in } \\
\mu \mathrm{g} / \mathrm{m}\end{array}$} \\
\hline & 50 & 25 & 10 & 5 & 2.5 & 1 & 0.5 & 0.25 & 0.1 & \\
\hline Formonone & $74.97 \pm 0.9$ & $69.72 \pm 0.9$ & $64.68 \pm 1.0$ & $57.09 \pm 1.0$ & $45.69 \pm 1.0$ & $37.46 \pm 0.6$ & $29.31 \pm 1.4$ & $20.16 \pm 0.8$ & $12.05 \pm 0.4$ & \\
\hline tin & $7^{*}$ & $4^{*}$ & $4^{* *}$ & $7^{* *}$ & $1^{*}$ & $5^{*}$ & $8^{*}$ & $3^{*}$ & $7^{*}$ & 4.27 \\
\hline Quercetin & $\begin{array}{l}79.09 \pm 0.8 \\
07\end{array}$ & $\begin{array}{l}74.40 \pm 1.1 \\
53\end{array}$ & $\begin{array}{l}69.68 \pm 1.1 \\
25\end{array}$ & $\begin{array}{l}61.83 \pm 0.4 \\
87\end{array}$ & $\begin{array}{l}49.45 \pm 0.4 \\
06\end{array}$ & $\begin{array}{l}41.33 \pm 0.4 \\
79\end{array}$ & $\begin{array}{l}33.61 \pm 0.9 \\
81\end{array}$ & $\begin{array}{l}24.47 \pm 0.5 \\
94\end{array}$ & $\begin{array}{l}16.19 \pm 0.3 \\
25\end{array}$ & 2.6 \\
\hline
\end{tabular}

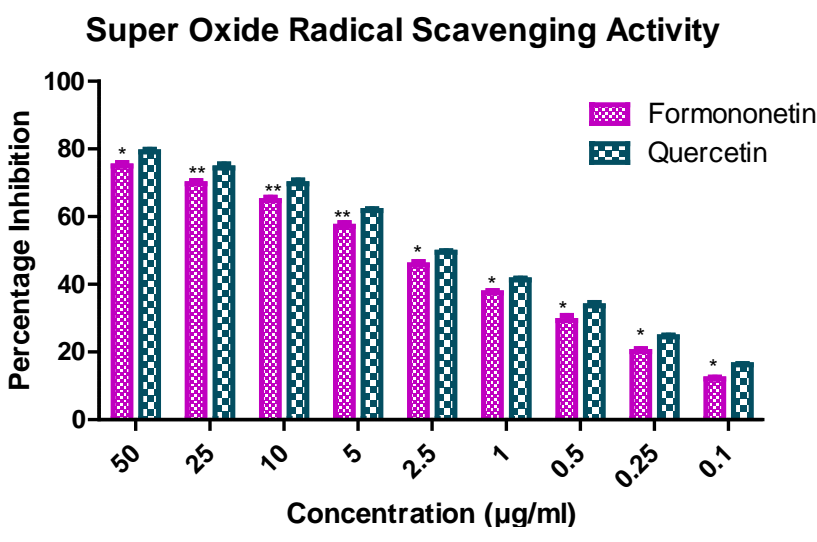

Fig. 5: Super oxide radical scavenging activity of formononetin was calculated and compared with quercetin i.e. standard. The activity increased in time and concentration dependent manner. The results represent the means \pm SEM (standard error of mean) from at least three separate experiments

\section{DISCUSSION}

In the etiology of a large number of major disease free radicals have their own impact because they can alter many crucial biological molecules leading to the loss of form and functions which can result in disease conditions. At various levels, antioxidants can protect against the damage induced by free radicals. The major sources of antioxidants are from dietary and other components of plants. Discovery of redox signaling is a milestone in establishing the relationship between free radicals, antioxidant, and functioning of various organs and organ system. Natural antioxidants are a presence in the traditional Indian diet, spices, and medicinal plants. The one strategy that is gaining importance in advanced countries is the higher intake of foods with functional attributes including a high level of antioxidant in functional food. In the coming decades, coordinated research involving a biomedical scientist, nutritionist, and physicians can make a significant difference in human health.

One of the main components of red clover plants is formononetin, and it is considered as a typical phytoestrogen. In the roots of Astragalus membranaceous, Trifolium pretense, Glycyrrhiza glabra, and Pueraria lobata formononetin occur naturally as isoflavones. Formononetin is one of the predominant isoflavones in Trifolium pratense L. The content of formononetin varies in different parts, among which the high content is in the leaf and the low content in the flower [11]. Legumes contain a large quantity of biochanin $\mathrm{A}$ and formononetin. Human liver microsomes could able to convert pro-estrogenic isoflavones to more potent phytoestrogens genistein through demethylation process and formononetin resulted in the production of additional metabolites such as 6,7-dihydroxy-4'-methoxy isoflavone, 7,8-dihydroxy-4'-methoxy isoflavone, and 7,3'-dihydroxy-4'-methoxy isoflavone a three new hydroxylated formononetin. Due to its structural similarity to 17 -estradiol, it can mimic estradiol's effect and therefore is considered as a "phytoestrogen" [12]. Its molecular formula is $\mathrm{C}_{16} \mathrm{H}_{12} \mathrm{O}_{4}$. Its molecular weight is $268.26408 \mathrm{~g} / \mathrm{mol}$ [13].

At the onset of diabetes and in the development of diabetic complications free radical involvement plays a major role [14]. Similarly, in the prevention of experimental diabetes in animal models and in type I and type 2 diabetes patients as well as reduce the severity of diabetic complications, scavengers of free radicals plays an important role. Due to the auto-oxidation of glucose, nonenzymatic glycosylation and polyol pathway, diabetic patients will have persistent hyperglycemia which leads to the generation of oxidative stress. Spontaneous reduction of molecular oxygen to superoxide and hydroxyl radicals, which are highly reactive and interacts will all biomolecules occur during the auto-oxidation of glucose. In addition, it also accumulates advanced glycation end products like pyrroles and imidazoles in tissues. Abnormalities in the cell and tissue function occur when cross-link occurs with advanced glycation end product protein with other macromolecules. The third mechanism by which generation of free radicals occurs in the tissues is a polyol pathway [15]. During this pathway, a huge amount of NADPH is deleted which leads to the impaired generation of antioxidants such as glutathione. Reactions with nitric oxide in endothelial cells, free radicals lead to the loss of vasodilatation activity. During aging and in diabetic conditions long-lived proteins, collagen and elastin undergoes continual non-enzymatic crosslinking which is mediated by advanced glycation end products [16].

The free radical NO• is produced from arginine by nitric oxide synthase (NOS) converts the substrate L-arginine to L-citrulline in the vascular endothelium. Adhesion of platelets and leucocytes, anti-inflammatory and antiproliferative regulation of expression and synthesis of extracellular matrix proteins is well protected by NO under normal conditions. Due to altered gene expression, as a product of the interaction of genes with the environment endothelial dysfunction can occur. Endothelial oxide synthase is an enzyme responsible for the production of NO. The polymorphism produced in this gene produce hypertension. Among the Indian population, the dysfunction of endothelium and insulin resistance is mainly responsible for hypertension, type II diabetes and atherosclerosis $[17,18]$. When cholesterol in the body gets oxidized it oxidize low-density lipoprotein (LDL) which triggers to initiate endothelial inflammation leading atherosclerosis and stroke due to vascular thrombosis. Many studies that have been carried out by different researchers, proved that high level of antioxidant rich food intake reduces the incidence of coronary heart disease [19]. Formononetin showed potent nitric oxide scavenging activity with the $\mathrm{IC}_{50}$ value of $5 \mu \mathrm{g} / \mathrm{ml}$ concentration.

The major target of free radical damage is DNA, which results in single or double strand break as well as various forms of base damage that produce products like 8-hydroxyguanosine, thymine glycol or abasic sites damage to deoxyribose sugar as well as DNAprotein cross-link. These factors are responsible for the formation of mutations and heritable changes in the DNA that result in cancer in somatic cells and fetal malformation in germ cells. Free radical involvement with tumor suppressor gene and proto-oncogenes causes different types of cancers in humans, which occurs through the accumulations of genetic changes that could be initiated by tobacco smoking and chewing, UV rays, virus, chemical pollutants as well as hormones like androgens for prostate cancer and estrogen for breast and ovarian cancer. Inducible nitric oxide synthase, as well as COX and LOX, can initiate carcinogenesis. The hydroxyl radical is found to be an important component that is responsible for the damage of DNA in the cells. Formononetin showed potent hydroxyl scavenging activity with the IC 50 value of $9.48 \mu \mathrm{g} / \mathrm{ml}$ concentration.

The process of cancer development and the risk that arise due to cancer can be inhibited by a variety of nutritional factors which can act as an antioxidant such as vitamin A, C and E, beta-carotene and 
micronutrients [20]. The progression of precancerous cells into malignant cells can be blocked by phytochemicals, which can block and reverse the promotion stage of multistep carcinogenesis [21] Mitogen-activated protein kinase (MAPKS) is one of the central components of the intracellular signaling network that maintain homeostasis. The prime targets of chemopreventive phytochemicals are NF-кB and AP1, which involves in numerous intracellular signal transduction pathways and mediates pleiotropic effects of both external and internal stimuli in the cellular signaling cascades [21]. Hydrogen peroxide, superoxide radical, is mainly responsible for the auto-oxidation of many biological components during the metabolism of the cell. Formononetin could able to scavenge hydrogen peroxide and superoxide radical with the IC 50 value of 5.0 and $4.27 \mu \mathrm{g} / \mathrm{ml}$ concentration respectively.

\section{CONCLUSION}

During the normal cellular metabolism, reactive oxygen species (ROS) and reactive nitrogen species (RNS) are produced which known for acts as secondary messengers which controls various normal physiological functions of an organism. Hormones, cytokines, and other mechanism regulate the production of No* by NOS and superoxide by $\mathrm{NAD}(\mathrm{P}) \mathrm{H}$. In order to protect cells against oxidative stress and maintenance of cellular functions ROS and RNS participate in various redox-regulatory mechanisms for maintaining "redox homeostasis". Our studies showed that, formononetin has the scavenging capacity against both reactive oxygen and reactive nitrogen species. It showed very potent antioxidant activity against various free radicals. So it is worth to use formononetin as an efficient drug to treat various diseases as well as to proceed for different types of formulations to target the main components that are responsible for causing different disease.

\section{CONFLICT OF INTERESTS}

The Authors declare that there is no conflict of Interest

\section{REFERENCES}

1. Wulf Droge. Free radicals in the physiological control of cell function. Physiol Rev 2002;82:47-95.

2. Devasagayam TPA, Tilak JC, KK Boloor, Ketaki S Sane, Saroj S Ghaskadbi, Lele RD. Free radicals and antioxidants in human health: current status and future prospects. J Assoc Phys India 2004;52:794-804.

3. Srividya AR, Dhanabal SP, Sathish Kumar MN, Vishnuvarthan VJ. The relationship between the Curcumin and antioxidant activity in Curcuma aromatica and Curcuma zedoaria rhizomes. J Free Radical Antioxidants Photon 2013;139:186-98.

4. Ammayappan rajam Srividya, Sangai Palanisamy Dhanabal, Vaithiyalingam Jagannathan Vishnuvarthan. Mutagenicity/ Antimutagenicity of plant extracts used in traditional medicine: a review. World J Pharma Res 2012;2:236-59.

5. Dharani B, Sumathi S, Siva Prabhu J, Padma PR. In vitro antioxidant potential of Prosopis cineraria leaves. J Nat Prod Plant Resour 2011;1:26-3.
6. Srividya AR, Dhanabal SP, Mistra VK, Suja G. Antioxidant and antimicrobial activity of Alpinia officinarum. Indian J Pharm Sci 2010;72:145-8.

7. Tushar Kanti Bera, Kausik Chatterjee Debidas Ghosh. In vitro antioxidant properties of hydroalcoholic extract of the seeds of Swietenia mahagoni. Biomarkers Genomic Med 2014;1:1-7.

8. Ammayappan Rajam Srividya, Abel Shalom, Raghu Chandrasekhar, Pottakadu Vijayan. Antioxidant, antimicrobial and in vitro cytotoxicity studies of Tithonia Diversifolia A. Grey. Int J Pharm Sci 2009;1:276-9.

9. Srividya AR, Shalom A, Chandrasekhar R, Vijayan P. Cytotoxic, antioxidant and antimicrobial activity of Polygonum Chinensis Linn. Int J Pharm Sci Nanotechnol 2012;4:1569-76.

10. Srividya AR, Aishwarya SN, Vishnuvarthan VJ. Evaluation of Antioxidant, Antimicrobial and cytotoxicity activity of Acorus Calamus Linn. Int J Pharmacol Res 2014;3:114-25.

11. Booth NL, Yao P, Totura S, Deng YF, Hedayat AS, Bolton JL, et al. Seasonal variation of red clover (Trifolium pratense L. Fabaceae) Overk CR. Isoflavones and estrogenic activity. J Agric Food Chem 2006;54:1277-82.

12. Databases on Food Phytochemicals and their health promotions. Available from: http://pubchem.ncbi.nlm.nih.gov/ compound/formononetin\#section=Names-and-Identifiers. [Last accessed on 20 Aug 2015]

13. Chemical comound database. Available from: www.Molbase. com/en/name-\%20Formononetin \%20Glucuronide.html. [Last accessed on 20 Jul 2015].

14. Lipinski B. Pathophysiology of oxidative stress in diabetes mellitus. J Diabetes Complications 2001;15:203-10.

15. Glugliano D, Cerriello A, Paolisso G. Diabetes mellitus, hypertension and cardiovascular disease: which role for oxidative stress. Metabolism 1995;44:363-8.

16. Vasan S, Foiles P, Founds H. Therapeutic potential of breakers of advanced glycation end products-protein crosslinks. Arch Biochem Biophys 2003;419:89-96.

17. Lele RD. The human genome project: its implications in clinical medicine. J Assoc Physicians India 2003;51:373-80.

18. Lele RD. Hypertension: molecular approach. J Assoc Physicians India 2004;52:53-62.

19. Chopra MU, McLoone M, O’Neill N, Williams DI. Fruit and vegetable supplementation-effect on ex-vivo LDL oxidation in humans, In natural antioxidant and food quality in atherosclerosis and Cancer Prevention. 1st ed. The Royal Society of Chemistry. Cambridge: UK; 1996.

20. Croce CM. How can we prevent cancer? Proc Natl Acad Sci USA 2001;98:10986-8.

21. Surh YJ. Cancer chemoprevention with dietary phytochemicals. Nat Rev Cancer 2003;3:768-80.

\section{How to cite this article}

- VJ Vishnuvathan, KS Lakshmi, AR Srividya. Study of antioxidant activity of formononetin by in vitro method. Int J Pharm Pharm Sci 2017;9(2):273-278. 